\title{
Cultural Signification within Inter-Religious Encounter in the Post-Conflict Ambon: Negotiation and Contestation of Identities
}

\author{
Steve Gerardo Christoffel Gaspersz \\ Faculty of Theology \\ Maluku Indonesian Christian University \\ Ambon, Indonesia \\ sgaspersz@yahoo.com
}

\author{
Fabian Novy Jocephs Souisa \\ Fishery Polytechnic \\ Tual, Indonesia \\ souisafnj@gmail.com
}

\begin{abstract}
This article obviously is an effort to comprehend processes of socioreligious identity formation through historical trajectory as well as identity contestation in contemporary daily life of Muslim-Christian communities of Leihitu in Ambon, specifically Wakal and Hitumesing (Muslims) and Rumahtiga (Christian). Those villages acknowledge that they have mythological narrative which based their gandong relationship. This research eventually would like to depict that development strategy of the local community, in a broader and fundamental sense, is able to be applied by understanding the local community's worldview as a manifestation of historical and cultural consciousness, which is formed throughout a long and dynamic living experience. At that point, it offers a novel perspective about a cultural strategy for community development with orientation on discovering intrinsic values of local tradition as foundation to absorb and adapt social changes in accordance with existing local wisdoms that actually are their social and cultural capital. Certainly, the result of this research is only a model that offers to be tested continuously in changing sociopolitical and cultural contexts. This research ends right on the dot where other subsequent researches must move on to discover and reconstruct development models which take sides for the better future and life of the globalized-local 'glocal' communities in Indonesia.
\end{abstract}

Keywords - Leihitu, identity, habitus, cultural transformation

\section{INTRODUCTION}

The issue of identity construction has indeed been prominent issue since the colonial era until today in Indonesia and Maluku. It became sensitive political issue even before the national independence in 1945 and stronger mainly since the New Order regime implemented politics of cultural domination and during around thirty two years succeeded in using religion and ethnicity as ideological mechanism in managing plurality of Indonesian society.[1] Then, local language becomes an arena of contestation for negotiating identity, including religious one, between two social religious-based groups in Ambon Island.

Religious-based conflict erupted in Maluku islands around 1999-2005, at certain extent, demonstrated the basic social problem which affected the process of identity construction among Ambonese people internally or between Ambonese with other social groups externally. It brought about dimensions of new understanding for being Ambonese and being Christian or
Muslim in certain sociocultural context of Maluku. This article attempts to comprehend processes of socioreligious identity formation through historical trajectory as well as contestation of identity in contemporary daily life of Muslim-Christian communities of Leihitu in Ambon.

The process of identity construction, in the case of the Muslim communities, had been taking place both as response toward social changes within society itself and vis-à-vis the existence of other social groups whose different ethnic and religious backdrops, especially immigrants and Christianity. Muslim communities of Leihitu have been living together as traditional thirteen villages (negeri adat) - with few Christian villages such as Alang, Liliboi, Hatu, Rumahtiga - along northern coastal area of Ambon Island. Along with Hatuhaha in Haruku Island, they are the largest Muslim population in southern Maluku. Historically, Muslim Leihitu had been playing vital roles in social formation of Ambonese society and vigorously demonstrating the feature of Ambonese Islam either in demographic composition or preservation of Ambonese Islamic tradition.

Cultural performance of Muslim Leihitu, in many ways, demonstrates the conservation of Ambonese Islamic tradition until today even though some aspects have changed. In addition to resistance against the colonial rulers, however, Leihitu's history and its social life are much loaded with internal conflicts of either intervillages or interfamilies. The cause and range of conflicts are multifold: from borderlands between neighboring villages and tensions among youth groups to disputes around traditional authorities among elite families and their descendants or followers. Some conflicts could be solved through cultural approaches or adat rituals mediated by traditional elders. Others remained even escalated into intervillages hostility until handled by the law enforcement. On the basis of their fieldwork in Hila, Frans von Benda-Beckmann and Tanja Taaleshow that conflicts in Leihitu, among others, caused by the ambiguity of perceptions on property rights in terms of (1) land registration; (2) money transfers; (3) changes in land use.[2]

Variables of cultural dynamic, process of identity construction as Muslim and Ambonese, relation with Christianity and social changes that occurred since precolonial, colonial, and postcolonial times attract my curiosity to scrutinize further religious imagination and social construction 
undergoing in daily practical livesand experiences dealing with other and otherness in Leihitu. Resistance and negotiation are part of their cultural strategies to understand and accommodate changes and differences. Religious values, rituals, sacred symbolic interpretations, and daily practice life based on certain type of Islamic spirituality and Quranic textual interpretation might be regarded as their cultural capital to survive and maintain identity borderlines. The dialectic of Islamic/Christian values and local culture has been understood not as two different and separated dimensions but as an amalgamation of cultural capital delineates their identity as Ambonese Muslim (Salam) and Ambonese Christian (Sarane).

\section{Methodology}

\section{A. Paradigm}

This article is based on political anthropology paradigms, i.e. processual paradigm, which focuses on social-political structures in a specific researched community, historical construction of power relations between social agents, function of cultural myths and rituals in structuring social relationship and power sharing among individuals, clans or groups, culturalbased strategies to pursue common goals, and sacred legitimacy of leaders which is socially viewed as an intersection of spiritual and political authorities.[3] Several key concepts such as power, legitimacy, support, faction, leadership, conflict, political field, political arena, and some others were composed in a diachronic framework that analyzed them as temporal and spatial processes.[3]

\section{B. Identity as Signification Process}

The notion of identity provided by Burke and Stets (2009) and Jenkins (2008) is going to apply as working definitions of this study. They demonstrate that identity has dual-constructive dimension, i.e. invidual and social. Everyone has multiple identities inasmuch they play multiple roles, member of multiple groups, claim his/her self as multiple personal characteristic, and also shares each other various meaning of identity as member of society. Although emphasizing more on individual identity, but they realize that individual cannot be separated totally from society or social structure and living his/her life within society. Instead of understanding it as 'thing', identity is rather a signification process acted by human being throughout his/her life individually and/or collectively. The signification process is always taking place in certain environment - and decisively influenced by it - where s/he lives in and doing activities. Identity is always a process of becoming and not such a thing that one can have but one does.[4]

\section{Culture, Power, and Reproduction}

All cultural symbols and practices such as artistic tastes, style in clothing, eating habits, even religion, science, philosophy, and language, represent interest and function to enhance social distinctions.[5] The struggle for social distinction, whatever its symbolic form, is a primary dimension of all social life.[6] Pierre Bourdieu pays theoretical attention to issues of power relations among individuals, groups, and institutions. Power stands at the heart of all social life and not a separate domain of study, where its exercise requires legitimation. Symbolic power relates to the conceptualization of all symbolic systems, which concomitantly demonstrate three interrelated but distinct functions: (1) cognition symbolic systems as 'structuring structures': as a means for ordering and understanding the social world. Language, myth, art, religion, and science, in this sense, represent different ways of cognizing the world; (2) communication - symbolic systems are 'structured structures' or 'codes' function as instruments of communication and as instruments of knowledge, which exercise a communication and social integration function; (3) social differentiation - not only provide cognitive and integrative functions, symbolic systems also serve as instruments of domination.

\section{The Agency/Structure Issue}

Bourdieu advocates relational method as the basic tool for imposing the necessary epistemological breaks with both subjectivist and objectivist forms of knowledge. In terms of agency/structure, he proposes for connecting agency and structure in a dialectical relationship by which moving analytically beyond the dichotomy of subjective/objective through conceptualizing action as integrative thinking through which micro/macro, voluntarist and determinist dimensions are incorporated into a single conceptual movement rather than isolated as mutually exclusive forms of explanation.

Individual and society are not two separate sorts of being but always interconnected or relational as two dimensions of the same social reality.[6] The idea that actors are practical strategists is linked to social structures through the concept of habitus: (1) 'a system of lasting, transposable dispositions which, integrating past experiences, functions at every moment as a matrix of perception, appreciations, and actions and makes possible the achievement of infinitely diversified tasks, thanks to analogical transfers of schemes permitting the solution of similarly shaped problems' and the second; (2) 'a system of durable, transposable dispositions, structured structures predisposed to function as structuring structures, that is, as principles which generate and organize practices and representations that can be objectively adapted to their outcomes without presupposing a conscious aiming at ends or an express mastery of the operations necessary in order to attain them'.[7]

\section{E. Fields of Power}

Practices occur in structured arenas of conflict called fields. This concept links the action of habitus to the stratifying structures of power in modern society, "an array of relatively autonomous but structurally homologous fields of production, circulation, and consumption of various forms of cultural and material resources".[6] Field intercede the relationship between social structure and cultural practice, and defines the structure of the social setting in which habitus operates.

Field stands for arena of production, circulation, and appropriation of goods, services, knowledge, or status, and the competitive positions held by actors in their struggle to accumulate and monopolize these different kinds of capital. It may be thought of as structured spaces that are organized around specific types of capital or combinations of capital. The notion of space per se contains the principle of a relational understanding of the social world. It affirms that every reality 
designates resides in the mutual exteriority of its composite elements.

\section{F. Religious Identity and Modernity}

Religious reality and religious identity fundamentally are reflection of dialectical sides between agency (religious leader, charismatic person) and social structure (both religious institution and social organization). The understanding of religious identity in such framework leads to see further that in the construction of religious identity one includes two belief elements, i.e. belief of superior being or divine power (idea of divinity) and belief that the divine power may be disseminated to and reproduced by certain others. These beliefs come to an arena (field) of power relations in which undergo negotiation processes between 'self' and 'other'; 'in-group' and 'outgroup'; 'individual' and 'social'. By using Bourdieu's relational method, it is a social space which attracts both individual and social interests to encounter one another and create the web of symbolic meanings in society.

Commonly, modernization is comprehended by the combination of differentiation and rationalization by which some parameters are determined, such as emphasis on individualism, democratic politics, liberal values, norms of efficiency and economic growth. It undermines tradition by cutting off the communal and social foundations that supported religion as a traditional institution.[8] 'Modernity' in this study is no longer anchored to unilinear process of modernization and a singular-global modernity but in variety of modernities, i.e. multiple modernities since modernity and Westernization are not identical. "Against conventional convictions, which emphasize the primacy of the economic system as the substructure of society, the conception of multiple modernities highlights th cultural dimensions of modernity and its locally specific characteristics."'[9]

\section{G. Settings: Hitumesing-Hitulama, Wakal and Rumahtiga}

Hitumesing and Wakal are two of sixteen Muslim villages (negeri) in Leihitu Peninsula, northern part of Ambon Island. These villages are neighboring about four kilometers with Hitulama in the middle of them. Administratively today these three villages are part of Kecamatan (sub-district) Leihitu that consists of 11 villages: Asilulu, Ureng, Negeri Lima, Seith, Kaitetu, Hila, Wakal, Hitulama, Hitumesing, Mamala and Morela; and KecamatanLeihitu Barat that consists of five villages: Larike, Wakasihu, Allang, Hatu and Lilibooy.

Demographically, it is difficult to determine borderline between Hitumesing and Hitulama. The villagers live in intersection areas and mixture settlement so that it is hard for non-villagers to identify which resident of Hitumesing and Hitulama. From the villagers' viewpoint, as also affirmed by Shahlan Pelu (Raja Hitulama), it is a kind of unnecessary differentiation for they convince both as one family, i.e. the people of Tanah Hitu. The only sign that marks differentiation of those villages is houses of raja Hitumesing and raja Hitulama with distance about 500 meter. Both villagers of Hitumesing and Hitulama even conduct daily prayer and Friday Prayer at one mosque locates in opposite to the house of raja Hitumesing. Specific location of the mosque is regarded as mark of religio-cultural legitimacy that Hitumesing is the original village before the Dutch separated them into two different administrative systems. There is belief that the original village or negeri tua has raja's house in opposite to a mosque that symbolize the unity of religion (Islam) and local custom. There is also the common notion that the mosque should be built in opposite to the raja's house due to when raja goes for Friday Prayer he should not walk pass through under people's roofedge.

Nevertheless, considering their kinship relations both communities attempted to manage such inevitable situation by stressing mutual understanding as one family of Hitu. Hence, according to Abdullah Pelu, raja of Hitumesing, in many tensions and/or for administrative manners they rely much on kinship approach rather than formal identity either as resident of Hitumesing or Hitulama to reach mutual understanding and living together for generations. In that manner, instead of village, the mosque or religion (Islam) has been playing pivotal role to unify both communities of Hitumesing and Hitulama. The unity has been indicated by having one mosque as commonplace for religious gathering and events. "Islam unites us as brother/sister of Leihitu," Musa Hurasan, imam of negeri mosque, says.

The implementation of regional autonomy and transformation of national leadership in the post-Suharto periods subsequently have been producing democratic governmental policy by providing more authority to regions for managing internal administration and resources. These changes have wider implication politically and culturally upon local communities' life in village. Traditional power relations survived hierarchically while sociopolitical mechanisms had changed radically. For instance, political mechanism of election for village/district/subdistrict headmen recently conducts directly and no longer determined by the regional representative council (DPRD). Space of political competitiveness opens wider and more democratic, but at the same time generates a high-risk competition within community per se and/or inter-communities in Leihitu.

Nevertheless, the election and confirmation for being raja are still strongly guided by adat cultural mechanism. Raja should be assigned from raja's mataruma (family) which means giving small opportunity for someone derives non-raja family to be raja. Raja's position in general is held by someone whose direct descendant of senior raja (father) or mataruma parenta as a kind of traditional elite class. The senior raja will appoint his youngest son as his successor. In doing his daily duty raja is assisted by adat officials, i.e. imam (head of mosque, religious authority), jurutulis (administration), marinyo (announcer), kewang (environmental affairs). Under the core structure of village authority there are heads of soa (association of some families or clan) whose responsibility to help raja in smaller unit of village administration namely dewan soa (soa council) led by matitauweng.

However, during the post-Suharto periods or Reformasi 1998, decentralization and democratization have been bringing about adat revitalization and enforcement to raise regionalism. Many villages, especially traditional one, in Maluku attempt to re-imagine their adat law for re-establishing adat structures and principles. Decentralization has opened chances to reconfirm their adat identity hand-in-hand with Islamic expression. 
Reformasi 1998 led indigenous people to great momentum to revitalize the adat sense than they experienced during previous regimes, particularly New Order. Today, most traditional village in Leihitu has been resurrected adat structure and adatbased legitimacy for authoritative leadership.

In addition to village authority represented by raja, Hituese view mosque as the center cosmos of religious life. The legitimacy of raja is also determined by how far he is supported by imam as religious representative or supporting religious affairs as one of his basic influential power before the people. Religion and politics in Leihitu tend to be viewed as one entity in strengthening the local power as well as strategic political management. That is the reason raja and imam are regarded as two integrated power in the saniri negeri structure. For instance, any adat conversation or bicara adat deal with a mosque (religious affairs) is conducted in baileu or house of adat. Baileu is managed by maulana, a religious board whose task for mosque management, maintenance and development. Imam masjid or the head of mosque takes responsibility to lead ibadah or worship/prayer.

Village administrator consists of three core elements: raja, pati, orang kaya. The Raja's leadership is held by several generations of mataruma Pelu. The term orang kaya has no clear meaning. As Manusama (1973)[10] notes, even Rijali, Rumphius and Valentijn used this term vaguely, but commonly it refers to a lower position under raja and pati. Some informants argued that the term orang kaya originally refers to newcomer who received higher political status within the traditional village administration. Pati is no longer exists in the Hitumesing village administration today. During the Dutch colonial time statuses of raja and orang kaya was interchangeably depending on the government's evaluation toward their achievement. For instance, although Hitumesing has a larger territory than Hitulama but the Dutch colonial government had given status orang kaya, not raja, to its administrator.

Rumahtiga is one Christian village which administratively under the sub-district of Teluk Ambon, Ambon municipality, along with eight other villages: Laha, Tawiri, Hative Besar, Wayame, Tihu and Poka. Those villages are neighboring with villages of the sub-district Leihitu Barat (Alang, Hatu, Liliboi) and Leihitu in northern part of Ambon Island, which administratively under the district of Central Maluku (Statistik Daerah Kecamatan Teluk Ambon 2016). Geographically, Rumahtiga has borderlines as follows: [a] northern side with Wakal and Hitumessing; [b] southern side with Ambon Bay; [c] eastern side with Hunuth-Durian Patah, adat territory of Halong; [d] western side with Hatiwe Besar.

As a typical Christian village in Ambonese islands, Rumahtiga has overlapped status as adat village and congregation of the Protestant Church of Maluku (GPM). In the daily life of the villagers there are two decisive institutions, i.e. saniri negeri which has political authority to rule administration matters under raja leadership and congregational assembly which manage congregational issues under pastor leadership. The community members always have a doubleidentity both as villager and church member. These institutions work together sometime in cooperative ways, but some other times with contradictory features since they have no bold sociological boundaries - one community with two authoritative institutions and distinct leaderships. The relationship between religion and adat is more dialectical than hierarchical as in Ambonese Muslim community. It is a typical feature of most Christian villages which differentiate them with Muslim villages in Ambonese islands.

\section{NeGotiating RELIGIOUS IDENTITIES AND CULtURAL AUTHORITIES}

The setting of three villages demonstrate sociocultural processes by which people construct their understanding about history, social changes, power relations and contestation of identity on the basis of cultural and religious dimensions. Essentially, the history of religions, particularly Islam and Christianity, in Maluku is the history of political economy.[11] asserts it explicitly in the dynamic context of Southeast Asia: "More than half the population of Southeast Asia adopted Islam or Christianity in some sense during the age of commerce." He explains further about wider scope of historical elaboration of social dynamic and complexity of Southeast Asia by which one discovers many aspects interwoven, such as economic interests, power struggle, ethnic identity construction, religious contestation, and so forth.

Description of sociocultural contexts of those three traditional villages in Ambon demonstrates that religious dynamic in each village strongly influences their social life and power relations. Many empirical and symbolic expressions might be seen throughout everyday internal social activities and sociocultural relations. Religious expression plays a pivotal role to form sociocultural characteristics which in turn influences another way around religious characteristics of Islam and Christianity in those three villages.

Historical viewpoint and contemporary social reality are subjects of discourse to discern negotiating process of religious identity as manifestation of power relations. Religion is moving for being structured structures and structuring structures through power relations in historical narratives and contemporary social reality. It is manifested into habitus which then influencing human's way of being religious and interreligious relationship in social context of Maluku and Indonesia. Religion plays pivotal roles as social capital which, on the one hand, stimulating sociocultural transformation and, on the other hand, preserving social distinctions and/or identification that potentially create social segregation even violent conflict. Dialectical conflation between cultural and religious expressions is clearly seen mainly in political institutions in Wakal and Hitumesing. In Rumahtiga, such expression performs in more segregated characters as result strictly separation between gospel and adat, or church and state. The different historical and sociocultural contexts constitute typical understanding about self and community, but at the same time also constituting self-understanding which relates substantially to the other, either Christian or Muslim.

Such different dialectical conflation between negeri Salam (Muslim community) and negeri Sarane (Christian community) has been articulated through religious rituals which determine how the concept of otherness is formed, absorbed, 
accommodated, harmonized dialectically so that selfunderstanding is related creatively with the other. The dynamic of self-identification and the construction of habitus have been affecting the concept and practice as Salam (Ambonese Muslim), Sarane (Ambonese Christian), and also the others (migrant ethnic groups) in daily social encounter and political discourses within their daily social life.

The social changes bring about an implication to contextualize religious doctrines and practices while still referring to the main religious principles of Islam and Christianity. The contextualization of religious doctrines and practices is taking place with different directions. In Muslim communities, Islamic tenets and practices are articulated through hybridity of local culture, as statement 'adat is host, religion is guest'. The flexibility to accommodate religion and culture has been determined also by social structure where raja rules as both community leader and religious adviser. He has holistic authority ruled by adat laws and from soa parenta as well as mataruma parenta. Religious scholars or ulama at most Muslim villages have positions hierarchically under raja authority. There is no power-sharing, but the division of roles since the power and authority are centered to the raja.

Christian communities, conversely, are articulating Christian doctrines and practices by drawing demarcation lines between religion and local culture. Christianity and adat tensions have been determined by different theological perspectives of pastor (church) and raja (adat). Pastor represents 'outsider' ( $\mathrm{s} /$ he has an out-group identity-marker) and 'modernity' ( $\mathrm{s} / \mathrm{he}$ comes from higher educational backgrounds - at least, bachelor degree) within village community/congregation s/he served. As an outsider, the pastor has no obligation to follow adat law but $\mathrm{s} /$ he usually gives respect on it.

The pastor also holds church authority as head of the congregation who plays significant roles as organizer and manager for all congregational programs and activities socially and spiritually. His/her position is not under raja or saniri negeri but independent and equal with even larger influences than raja. Meanwhile, raja authority is more determined by adat law, soa parenta and mataruma parenta. Thus, Ambonese Christian communities are facing two opposite authoritative institutions within one community/congregation. These institutions have been competing one another implicitly or explicitly to gain more power over the community or congregation. Therefore, either formally or informally, power and authority have been shared.

Nonetheless, social changes bring about the shift of cultural mindset and identity formation within Ambonese Muslim and Christian communities. The shifting of cultural mindset has been influencing social and power relations intra-village and inter-village. In the dynamic of social changes each community endeavors to negotiate their identities through religious and adat rituals by which they reconfirm collective memories and myths, as well as reconstructing set of meaning about their existence in relation to others and reproducing contextual cultural narratives.

Certainly, there are various conflicts of interest in the process of negotiating identities which in turn disembogue on contestation of identity politics by utilizing political and cultural authorities. The phenomenon will perpetuate patronclient relations which actually already exist in local cultures, but now achieve new meaning in accordance with political interests. Therefore, power relations of inter-actor and intercommunity are becoming more complex (semantic accretion).

The meaning of otherness has been formed within inclusive and interactive encounter that in turn positioning individual/group in a situation which their identity could be understood primarily as intersecting identities. Intersection identities are moving, dynamic, plural, and hybrid identities determined by power relations which directing cultural patterns of society in relational ways with others.

That is why the interpretation about 'who I am or who we are' and 'who s/he is or who they are' becomes a complex and sophisticated process since embracing multifold dimensions of meaning and interpretation which is affected by social context and relations within certain social space and political arena. Religious identity is one important variable in Moluccan social space and political arena. Nevertheless, it could not stand independently since religion itself has been 'structured structures and structuring structures' so that it has multilayer of meanings and interpretations.

The context of Ambon/Maluku as part of process 'becoming Indonesia' with all historical dynamic and social transformation until today - as seen during my field research - demonstrated that negotiating identities (religion and ethnicity) have been undergoing in the context of institutional and dimensional networking. The logic brings to a critical consciousness to avoid cultural traps which construct meaning of identity in essential mindset which is simply strengthening stigmatization and stereotyping toward otherness.

\section{CONCLUSIONS}

- Modernization of Indonesian society, which was signed by the formation of modern nation-state of Indonesia, brought about implications such as the rationalization of political mechanism so-called the government bureaucracy since the Dutch colonial periods to the present day, the logic structure of national regulations which is distinguished from a myth-based political authority, people's representatives and the construction of national identity imagination to organize pluralistic society of Indonesia on the basis of democracy system as a kind of social contract among different ethnic groups.

- The restructurization of democratic institutions has opened a room for public engagement in implementing government policies at national and local levels. Meanwhile, the decentralization movement has driven the revitalization of local traditions muted by the so-called politics of national culture that obviously lies on the single majority ethnic culture (Javanese). The adat institutions have been dysfunctional for years since the establishment of the New Order regime, but recently get a political momentum to be resurrected as sociocultural mechanism for managing societal life at the local levels. 
- The emergence of new meanings about structures of local tradition (e.g. pela and gandong) that cannot be dealt with only as the structural transformation of sociopolitical institutions but rather about the impact of state's sociopolitical transformation as a macro dimension which influences power relations and everyday social relations at the local level. Sociocultural transformations are not merely understood as the implication of structural changes but also as the involvement of actors as prime agencies who play pivotal roles to determine the direction of such transformation.

- The ontological relations between religions (Islam and Christianity) and local tradition (adat) have been taking place within the dynamic different contexts in Muslim and Christian communities which then produce typical religious forms. Such forms could not be generalized or compared to other sociocultural contexts of Indonesian pluralistic society. Islam and Christianity in Ambon cannot define themselves by detaching their relation one to another. In other words, an effort to understand Moluccans identity inevitably must incorporate sociocultural and religious dimensions as integral concepts and practices which form their social habitus. In that way, one can reach the ontological realm of 'Salam' and 'Sarane'. So, Salam-Sarane is not only another name for or translation of 'Muslim' and 'Christian' but the cultural expression depicting how adat (local element) and religions (global elements) strongly determine their common understanding and practical life as the relational existence - the social fact of glocalization.

\section{ACKNOWLEDGMENT}

My deepest gratitude and appreciation goes to Graduate Program of UKIM as well as all communities whose great willingness to support my field research in Ambon.

\section{REFERENCES}

[1] F. L. Cooley, Altar and Throne in Central Moluccan Society. New Haven: Dissertation at Yale University, 1961.

[2] D. Mearns and C. Healey, Remaking Maluku: social transformation in eastern Indonesia. Special Monograph No. 1, Center for Southeast Asian Studies Northern Territory University, 1996.

[3] D. V. Kurtz, Political Anthropology: paradigms and power. Boulder: Westview Press, 2001.

[4] R. Jenkins, Social Identity. New York: Routledge, 2004.

[5] P. Bourdieu, Language and Symbolic Power. Cambridge: Harvard University Press, 1991.

[6] D. Swartz, Culture and Power: the sociology of Pierre Bourdieu. Chicago: University of Chicago Press, 1977.

[7] P. Bourdieu, Outline of a Theory of Practice. Cambridge: Cambridge University Press, 1977.

[8] B. S. Turner, Religion and Modern Society: citizenship, secularization and the state. Cambridge: Cambridge University Press, 2014.

[9] V. Gottowik (ed.), Dynamics of Religion in Southeast Asia: magic and modernity. Amsterdam: Amsterdam University Press, 2014.

[10] Z. J. Manusama, Historie en Sociale Structuur van Hitu: tot het midden der zeventiendeeuw, Utrecth: Moluks Historisch Museum, 2004.

[11] A. Reid, Southeast Asia in the Age of Commerce 1450-1680, vol. 2. New Haven: Yale University, 1993. 